\title{
144. 緑化に関する条例等における規定の構成要素とその時代変化に関する研究
}

Study on the components and their changes of guidelines for urban greening of local government ordinance

植田 直樹*，瀬島 由実加**，村上 暁信*** Naoki Ueda*, Yumika Sejima**, Akinobu Murakami***

\begin{abstract}
This study aimed to discuss appropriate urban greening of private land through the examination of quantitative leading guidelines for greening of local government code. By collecting descriptions on urban greening of ordinances, and comparative analysis using them, it was revealed that $27.7 \%$ of prefectures and $85.0 \%$ of ordinance-designated cities had quantitative leading guidelines for greening. Regarding to the foundation of them, most of them were affected by Factory Location Act and Conservation of Urban Greenery Act, and the rest of them were affected by Landscape Act or global warming countermeasure. Green cover ratio was used in the codes, but there were variety of the way to calculate the ratio. By classification of them, they were proved to be consisted from seven main rules. Based on the results of the analysis, the problems and how to develop new guidelines by controlling details of the seven rules were discussed.
\end{abstract}

Keywords: Greening ordinance, Greening private land, Ratio of greening 緑化条例, 民有地緑化, 緑化率

\section{1.はじめに}

都市化の進展による都市部の緑地の減少により，ヒート アイランド現象や生物多様性の喪失, 自然との触れ合いの 場の減少といった様々な都市環境の課題が議論されるよう になって久しい。さらに都市部の緑地の存在は都市生活の 快適性を図る要素として重要であることから,グローバル な都市競争力の一つの要素として取り扱われるようになっ ている注1)。

そのような中で，公的資金を投入しての公園緑地の整備 は，特に地価の高い都市部においては実現に困難が伴い， それを補うものとしていわゆる「緑化制度」と呼ばれる民 間事業での緑の創出を誘導する施策が実施されてきた。一 定の要件の建築行為や開発行為において必要となる緑化の 内容を提示し要求する制度であり，民間敷地の緑の物理的 な量と形態を誘導する効力を有しているため, 現実の都市 部の緑地の一定部分を形づくり，都市環境の改善に大きな 役割を果たしている。また，国土交通省は「新たなステー ジに向けた緑とオープンスペース政策の展開について」1) の中で, 少子高齢化と人口減少の進展, 都市への人口集中, 税收減による財政の深刻化，などの社会状況を背景に，こ れからの時代における新たな時代の都市に相応しい緑と才 ープンスペースが重視すべき観点の一つとして官民連携を 提示し, 緑とオープンスペースのストック効果を高めるこ とを掲げている。民間緑地の果たす役割は今後さらに重要 性を増してくると考えられる。

緑化制度についてはすでにいくつかの既往研究がある。 渡辺 ${ }^{2)}$ は, 首都圈各市区における緑化政策の実施状況を 明らかにしているが，ここでいら緑化政策は緑化啓発運動 や公有地の緑化なども含む包括的なものであり，個々の政 策の構成や民有地の緑化誘導の具体的手法にまでは言及し
ていない。御手洗ら ${ }^{3)}$ は, 47 の緑化義務を課する法律や条 令を研究対象としてその特徵を類型化し, 対象とする地域 や履行確認手段, 争訟手段, 維持管理規制について指摘し ているが，緑化に関する具体的な誘導手法としての緑化率 等については言及されていない。

緑化制度の内容と空間形成の関係性についての研究とし ては, 上野ら ${ }^{4)}$, 陳ら ${ }^{5)}$, 小野 ${ }^{6)}$, 鈴木 ${ }^{7)}$ などの研究があ る。このうち, 小野 ${ }^{6)}$ は緑化制度と地価の関係を分析し, 接道緑化や建築物緑化は，建築行為への制限が少なく外部 性が高いことを理由として，制度強度が強いほどに地価に 正の影響を与えることを明らかにしている。鈴木 ${ }^{7)}$ は東京 の公開空地の実態分析から，公開空地面積と緑化面積には 強い正の相関があることを示し，都心三区では緑とオープ ンスペースの量的不足を補うストック形成が図られている としている。しかしこれらは総合設計制度により生み出さ れた公開空地を対象としているため, より広範に適用され る緑化制度とそれにより創出される空間との関係把握には 至っていない。

以上のような既往研究によれば，緑化制度には緑の物理 量の増加に加え, 緑の外部経済性を発揮させるような配置 への誘導効果があることが理解される。しかし既往研究は 開発圧力の高い東京などの大都市圈を対象としたものが多 く，全国にわたる緑化制度の状況を把握したものは見られ ないため，自治体によって様々に規定された緑化制度の内 容についての知見は十分には得られていない。

さらに現実の緑化誘導の状況においては緑化面積といっ た物理量の増加が着目されやすく, その結果として敷地の 奥や境界部に効果の乏しい緑地が設けられるという問題も 見受けられているが, その背景についての研究はまだない。 そこで本研究では，全国の「緑化に関する条例等」の内

* 正会員 株式会社三菱地所設計（Mitsubishi Jisho Sekkei Inc.)

** 正会員 東日本旅客鉄道株式会社（East Japan Railway Company）

*** 正会員 筑波大学システム情報系（University of Tsukuba） 
容を調査することによって，どのような具体的な規定を行 っているのかを把握して制度の特徵を分析寸ると同時に， 制度が物理量のみの増加を意図しているのか否かを確認し, また制定年代と名称を調べることで具体的な規定が時代す なわち社会的背景に応じてどのように変化しているのかを 把握することによって，これからの時代に対応した制度設 計について考察することとした。

\section{2. 研究方法}

国土交通省による都市緑化データベース ${ }^{8)}$ には「全国の 緑化・緑地保全に関する条例等の制定一覧と保全地区等の 指定状況」が公開されており，36 都道府県 508 都市で 721 (2014 年度末時点)の条例等が制定されている。これに よれば緑化に関する制度は，地方自治法に基づく「条例」 で定める自治体もあれば，条例ではなく行政指導の内容と して「指導要綱」や「実施要綱」として定めている自治体 もある。そのためデータベースのタイトルも「…条例等」 とされていると考えられる。本研究においてもこの認識に 立ち,「条例」や「指導要綱」「実施要綱」を調査の対象と して扱い，それらを「緑化に関する条例等」と呼ぶことと した。

データベースに公開された条例等の数值は緑地の創出と ともに既存緑地の保全を求めるものも含まれている值であ ることから，本研究では，日本の全体での制度の内容の違 いの有無を把握すること，かつ緑地保全ではなく都市化に 伴う緑化誘導の仕組从を研究対象とすること，を目的とし ているため, 日本の地方自治体のうち，都道府県(47 自治 体) に加えて都市化の進展と対策を行政課題としていると 考えられる政令指定都市 (20 自治体)を対象として，それぞ れの自治体が公開している行政文書(条例, 条例規則, 緑化 の手引き, 指導要綱等)を閲覧し, 緑化に関寸る条例等の有 無，および有している場合はその規定内容を調查した。調 查の方法は, 自治体ホームページにより条例等の有無(無の 場合は自治体の関連部署に直接問い合わせて条例等の存在 と参照すべき文書を確認した) と内容の確認を行った。調査 時期は 2016 年 12 月から 2017 年 3 月である。調査時点で公 開されているものを対象としたため，指導指針から指導要 綱への変更や条例への変更といった過去の履歷が存在する 場合は，過去の内容は対象外とした。

なお，上記都市緑化データベースによれば，都市緑地法 第 39 条に規定されている地区計画等において緑化地域制 度と同様の緑化の義務付けをすることが可能な「地区計画 等緑化率条例制度」を適用寸る自治体が 39 事例(2015 年度 末時点)ある。しかしこの場合は緑化の目的が地区計画の目 標に応じて設定されることから, 本研究の分析対象には地 区計画等緑化率条例制度は含まないこととした。

\section{3. 全国の緑化に関する条例等の状況}

各自治体の条例等を調査した結果を表-1 に示す。緑化に 関する条例等については, 20 の政令指定都市は全て有して
いたが，都道府県については 47 のうち 11 都道府県が有し ていなかった。これは県が所管する範用が広域にわたるの に対し都市化が課題となる都市域の面積が比較的小さいな ぞ，行政の重点施策の比率が小さくなることによると考え られる。

緑化に関する条例等には，(A)緑化に関する具体的基淮 を有するものと, (B) 方針のみを示寸ものが存在していた。 緑化に関する具体的基準を有する都道府県は 13 事例, $27.7 \%$ であり, 政令指定都市は 17 事例, 85.0\%にのぼって いた。これは都市化による人口集中が進む政令指定都市の 方が，緑化に関する具体的基淮の必要性をより大きく有し ているためと解棌できる。以降は，具体的基淮を有する合 計 30 の事例を対象に分析を行った。

表-1＼cjkstart緑化に関する条例等の保有状況

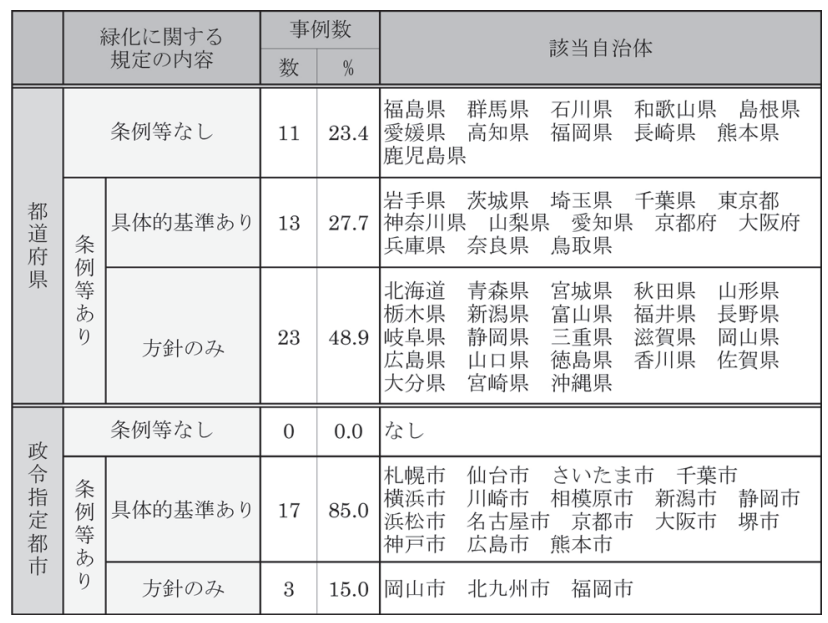

表2 分析した緑化の具体的な基淮を有する条例等

\begin{tabular}{|c|c|c|c|c|c|}
\hline \multicolumn{3}{|c|}{ 都道府県 $(13$ 事例) } & \multicolumn{3}{|c|}{ 政令指定都市 (17事例) } \\
\hline 1 & 岩手県 & 岩手県景覾計四 & 1 & 札䗷市 & 札幌市緑の保全七㓦出に関する条例 \\
\hline 2 & 茨城県 & 茨城県地球環境保全行動条例 & 2 & 仙台市 & 杜の都の環境をつくる条例 \\
\hline 3 & 埼玉県 & ふるさと埼玉の緑を守り青てる条例 & 3 & さいたま市 & さいたま市みどりの条例 \\
\hline 4 & 千葉県 & 千葉県自然環境保全条例 & 4 & 千葉市 & 千葉市工場等緑化推進要網 \\
\hline 5 & 東京都 & 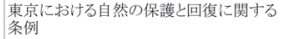 & 5 & 横浜市 & 緑の環境をつくり㕕てる条例 \\
\hline 6 & 神奈川県 & 自然㻴境保全条例 & 6 & 川崎市 & $\begin{array}{l}\text { 川崎市緑の保全及び緑化の推進に関寸る } \\
\text { 条列 }\end{array}$ \\
\hline 7 & 山梨県 & 山梨県環境緑化条例 & 7 & 相模原市 & 相模原市開発事業基淮条例 \\
\hline 8 & 愛知県 & 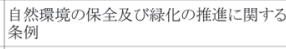 & 8 & 新渴市 & 樹木の保存及び緑化の推准に関する条例 \\
\hline 9 & 京都付 & 京都府地球温瞹化対策条例 & 9 & 静阔市 & 静阔市みどり条例 \\
\hline 10 & 大阪府 & 大阪府自然環境保全条例 & 10 & 泜松市 & 浜松市緑の保全及び䏍成条例 \\
\hline 11 & 兵庫県 & 環境の保全と㓱造に関与る条例 & 11 & 名古屋市 & 緑のまちー゙くり条例 \\
\hline 12 & 奈良県 & 奈良県景観条例 (奈良県景観啍画) & 12 & 京都市 & 京都市地球温䁔化対策条例 \\
\hline \multirow[t]{5}{*}{13} & 鳥取県 & 鳥取県景袏形成条例(鳥取県景視計面) & 13 & 大阪市 & 建策物に付属する緑化指導要網 \\
\hline & & & 14 & 堺市 & 堺市緑の保全と創出に関する条例 \\
\hline & & & 15 & 神戸市 & $\begin{array}{l}\text { 神戸市建築物等におけ関寸るる環境配慮の推進 } \\
\text { 条列 }\end{array}$ \\
\hline & & & 16 & 広島市 & 地球温䁔化刘策等の推進に関する条例 \\
\hline & & & 17 & 熊本市 & 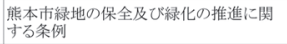 \\
\hline
\end{tabular}

4. 緑化規定の内容

次に条例等に記されている緑化の具体的基淮を定める規 定の内容について把握した。 
まず，すべての事例で，当該条例等の内容が適用される 事業を規定寸る項目【1緑化誘導対象規模規定】が存在し た。全 30 事例のうち 28 事例が事業の面積を用いて対象を 規定しており,敷地面積 (A), 行為面積 (=行為地面積) (B), 開発区域面積 $(C)$ がある值を超えた場合に適用寸る，とし ていた。建物規模(D)に着目寸る自治体もあり，建物の高 さや建築面積，延床面積，住戸数がある值を超えた場合に 適用する，としていた。

条例等が適用される場合に何をどのように誘導するのか を規定する項目について確認した結果，すべての条例等が 緑化率を用いて記述をしていた。緑化率とは，ある事業行 為面積のうち緑化されている面積が占める割合を指寸。

緑化率によって誘導する目標値は一律ではなく，事業の 内容によって差がつけられていた【(2)緑化誘導対象分類規 定】。事業の内容とはその事業が，どのような属性 (用途地 域や建ぺ率の指定状況）の土地で行われるのか(A)，ど のような事業用途なのか $(\mathrm{B})$, どの程度の規模で実施され るのか $(\mathrm{C})$ ，どのような開発手法で実施されるのか(D)， であった。またどこを緑化するのか (地上部か建築物上か)

（E）によって差をつけている自治体もあった。土地属性 によって誘導対象を区分する方法(A)を採用する事例が約 半数の 14 事例存在していたが, そのうち 8 事例はそれに事 業の用途 (B) や面積規模 (C)を組夕合わせていた。(D)の 開発手法により誘導目標を変化させていたのは東京都であ った。東京都では総合設計制度などの都市再開発諸制度を 利用して都市計画に規定される制限の緩和を受ける開発事 業の場合に, 必要緑化率が上増しされていた。公開空地の 創出を開発インセンティブとして取り扱うケースが多い場 合には，一般設計と同様の規定では不十分という自治体の 考え方が現れているといえる。

また，すべての条例等が緑化率を採用していたが，緑化 率の算出方法【(3)緑化率算出規定】には違いがみられた。 緑化率は「緑化されている面積」／「事業行為面積」で求 められるが，ここで分母に相当する事業行為面積の設定に は，(A) 分母となる数值を敷地面積とするタイプと，(B) 分母となる数值を空地面積 (非建ぺ面積) とするタイプ が存在した。全体の 7 割の 21 事例はAタイプであり, 残り の9事例はBタイプであった。Aタイプは建築面積に左右 されずに一定の緑化を求めることが可能であり, 非建ぺい 空間の規模とは無関係に緑化率が定められるが，Bタイプ は現実の非建ぺい空間に対する具体的な緑化誘導が可能で ある。Bタイプは指定建ぺい率の消化率によって緑化され る面積が変わり得ることから，Bタイプを選択寸るのは高 密な都市空間で現実に即した運用がし易いことが理由とし て考えられる。実際にBタイプ 9 事例のうち 8 事例は，指 定建ぺい率の消化率が高いと想定される都道府県市（東京 都, 埼玉県, 大阪府, 神戸市, 兵庫県, 熊本市, 京都府, 京都市) に多かった。

さらにBタイプには「空地面積=(敷地面積一建築面積)」 とするもの (緑化率分母タイプ(B-1)) と, 「空地面積 $=$ (敷
地面積一(敷地面積 $\times$ 建ぺい率 $\times \alpha$ ))」とするもの（緑化 率分母タイプ (B-2)) の二つが存在していた。後者を採用 するのは, 東京都, 京都府, 大阪府, 兵庫県, 京都市, 神 戸市と岩手県であった。

一方で, 緑化率算出の分子にあたる緑化面積の算出には, 様々な方法【4緑化量算出規定】がみられた。多くの自治 体がこれらの計算方法のいくつかをメニューとして示し, 事業者が選択できるようにしていた。まず(A)植栽される 植栽基盤（実際の植栽のために区画された土地の地表面の 面積）の面積を利用する緑化面積タイプと，（B)植栽され る樹木の樹冠の地上部一の水平投影面積を利用寸る緑化面 積タイプがみられた。Aタイプは樹木 1 本 1 本ではなく樹 木植栽地として面で算出する方法である。樹木植栽地とし てカウントするための植栽密度条件が示されていることが 多かった。Bタイプは地表面の被覆状況には左右されない。 Aタイプでは面的な緑被率向上や非舗装面の増加による緑 地の保水機能を向上させることでの都市の水循環回復など を誘導することが可能になる。これに対してBタイプでは 樹冠下の地表の舗装の有無は問われないため, 高木を植栽 すれば樹冠下空間を利用することが可能になる。設計者の 立場からは緑化率規定の達成と利用者の利便性向上を両立 させることが可能になるため, 高木利用のインセンティブ が働きやすくなり、高木植栽による緑視率の向上や熱中症 被害の防止効果などを誘導することが可能になる。タイプ の選択によって，自治体がより重要と考える機能を有した 緑地を誘導することが可能になるといえる。Bタイプはさ らに，実際の樹冠面積を計上するもの $(\mathrm{B}-\mathrm{a})$ と，樹高を基 準にみなし樹冠面積を設定するもの $(\mathrm{B}-\mathrm{b})$ があった。みな し樹冠面積の設定には, 植栽時の樹高を基準とするもの(B -b-1) と成長時の樹高を基準とするもの (B-b-2) があり, (B-b-1) はさらに，樹高別に分類(高中低木等) し，それぞ れにみなし樹冠面積を割り当てるもの $(\mathrm{B}-\mathrm{b}-1$ (1)) と，分 類はせず樹高を直接樹冠の直径に換算するもの $(\mathrm{B}-\mathrm{b}-1$ (2)) が存在した。これらを図にすると図- 1 のようになる。

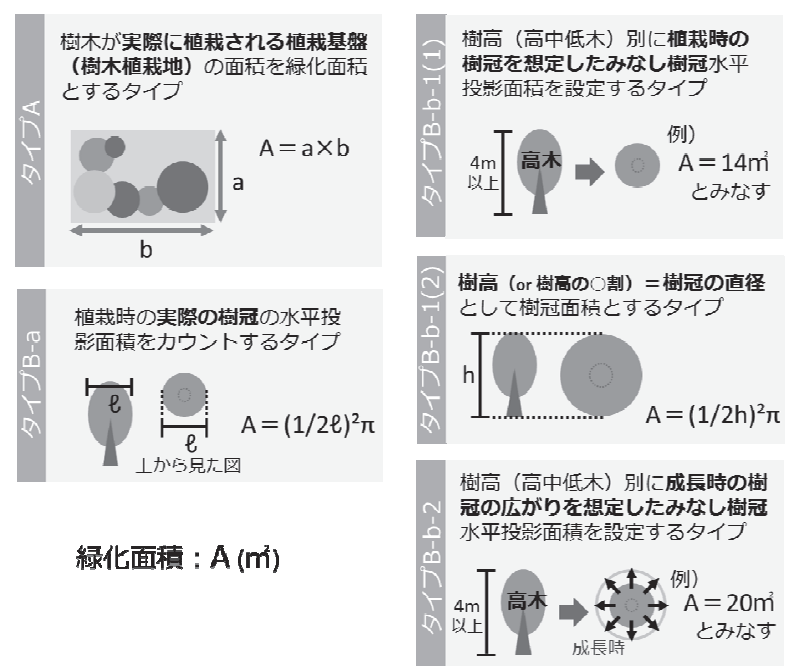

図-1 樹木の面積算定方法 (5 タイプ) 
自治体が提示寸るタイプの選択によって特徵のある緑化を 誘導することができるが，各事例の提示する算出方法をみ ると (表-3)，方法はひとつではなく複数用意されている。 様々なケースを組み合わせて事業者が算出方法を選択でき るようになっていることから，自治体が望む緑化に繋がる かどうかは事業者の判断によっている。

表-3 緑化面積算定方法

\begin{tabular}{|c|c|c|}
\hline 自治体名 & 緑化面積算定方法 & 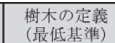 \\
\hline 岩手県 & 【タイプB-a】又は【タイプB-b-1(1)】 & 記載なし \\
\hline 茨城県 & 具体的記栽ふし & 記载なし \\
\hline 埼玉県 & 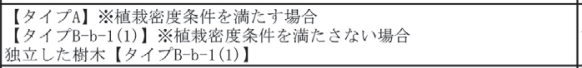 & 記載なし \\
\hline 千葉県 & 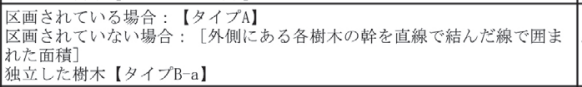 & 記载なし \\
\hline 東京都 & 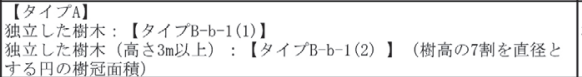 & $\begin{array}{l}\text { 榯高0.3m以上 } \\
\text { (植载時) }\end{array}$ \\
\hline 神奈川県 & 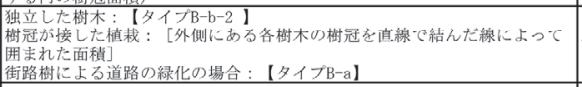 & 記載なし \\
\hline 山梨県 & 【タイブB-b-2】 & 記戎なし \\
\hline 受知県 & 具体的記载なし & 記載なし \\
\hline 京都府 & 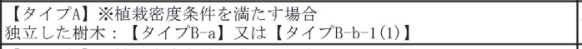 & 記载なし \\
\hline 大阪府 & 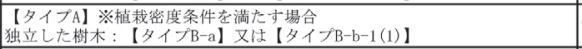 & 記載なし \\
\hline 兵庫県 & 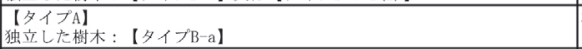 & $\begin{array}{c}\text { 樹高0.3m以上 } \\
\text { (椎栽时) }\end{array}$ \\
\hline 奈良県 & 【タイブB-b-1(1)】 & 樹高0.5m以上 \\
\hline 鳥取県 & 【タイプB-b-2】 & 記载なし \\
\hline 札惿市 & $\begin{array}{l}\text { 【タイプB-b-1(1)】 } \\
\text { ※接道部ホホーナスエリアゼは3倍 }\end{array}$ & 榯高0.3m以上 \\
\hline 仙台市 & 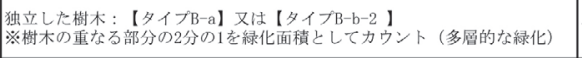 & 記载なし \\
\hline さいたま市 & 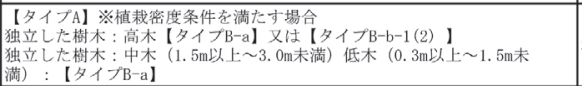 & 榯高0.3m以上 \\
\hline 千乗市 & 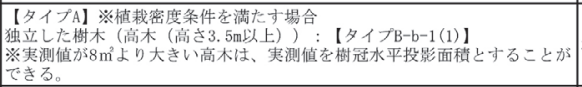 & 樹高0.5m以上 \\
\hline 横浜市 & 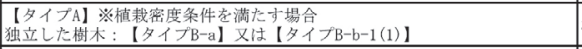 & 樹高0.4m以上 \\
\hline 川崎市 & 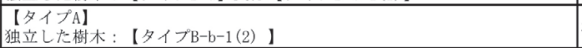 & 樹高0.3m以上 \\
\hline 相模原市 & 具体的記截なし & 記栽なし \\
\hline 新渴㭉 & 具体的記戈尔し & 記载なし \\
\hline 静岡市 & $\begin{array}{l}\text { 【タイプB-b-1(1)】 } \\
\text { ※楖木と地被植物が重なる部分は二重に計上可 (多層緑化) }\end{array}$ & 樹高1m以上 \\
\hline 浜松市 & 【タイプA】 ※植栽密度条件老満たす場合 + 【タイプB-b-1(1)】 & 記載なし \\
\hline 名古屋市 & 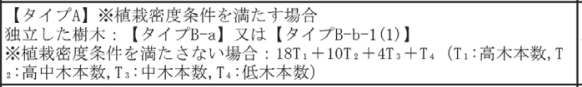 & 記載なし \\
\hline 京都市 & 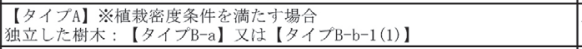 & 記載なし \\
\hline 大阪市 & 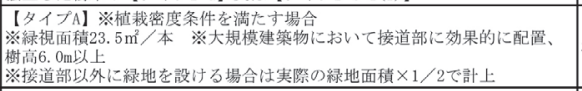 & 樹高 $0.3 \mathrm{~m}$ 以上 \\
\hline 堺市 & 具体的記载なし & 記载なし \\
\hline 神戸巾 & 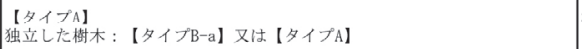 & 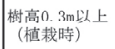 \\
\hline 広密市 & 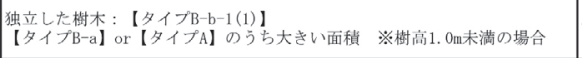 & 記载なし \\
\hline 能本市 & 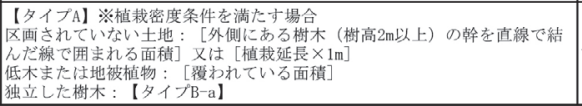 & 記栽なし \\
\hline 脚注） & 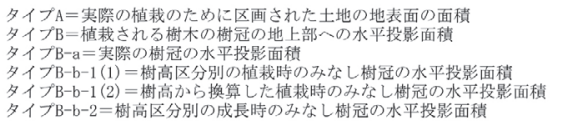 & \\
\hline
\end{tabular}

また条例等の規定の中には，緑化の配置場所に関する規 定を設けているもの【(5)緑化配置誘導規定】も存在した。 接道部における緑化が建築行為への制限が少ないうえに外 部性も高いという特徵があることは既往研究で明らかにな っているが，それらを誘導する規定を有しているものが 4
事例あった。接道部の緑化を誘導するもののなかでは, (A) 敷地の接道延長に対して緑化する割合を規定するもの（接 道緑化率タイプ）と，（B)接道部の緑化面積に係数を乗じ て割り増しするもの（接道部緑化面積割増タイプ）があっ た。Aタイプの事例では，東京都は敷地が道路に接する長 さ (接道延長) に対しての必要緑化延長を規定していた。 Bタイプの事例では, 札幌市が道路から $6 \mathrm{~m}$ の範囲をボーナ スエリアとして設定し，そこでの緑化は実際の面積の 3 倍 に換算することが可能であるとしている。広島市は接道部 の壁面緑化は面積を 1.5 倍に換算できるとしている。大阪 市は接道部に緑視面積という特別のみなし緑化面積を設定 しているのに加え，接道部以外では面積を $1 / 2$ にするとい った緑化配置誘導の工夫を行っていることが確認された。

建築物の緑化についても様々な規定【(6)建築物上緑化誘 導規定】がみられた。屋上緑化を地上部の緑化と同様に取 り扱うもの (屋上緑化タイプ $(\mathrm{A}))$ と, 地上部と屋上部の個 別の基準を有するもの(屋上緑化タイプ(B))がみられた。 また，屋上緑化タイプ(A)の中でも「屋上緑化を地上部の 緑化と同様に取り扱うが上限や制限を設ける」もの(屋上緑 化タイプ(A-2))が存在した。全体の緑化の $1 / 2$ 以内とする 上限を設ける事例(神奈川県)や，面積に係数 0.5 を乗じる 事例(大阪市), さらには地被緑化の場合は係数 0.5 を乗じ る事例(神奈川県)が確認された。これらは屋上緑化を認め つつも，地上部緑化をより重視しているために屋上緑化に 制限を設けているものと推測できる。また多くの事例で壁 面緑化を緑化面積に算入していた。壁面緑化については, 植物に被覆される面積を計上できるもの(壁面緑化タイプ (A)) と,植物に被覆される面積によらず壁面の高さを一律 に規定するもの(壁面緑化タイプ(B))が存在した。

さらに 10 事例で, 生垣を樹木としてではなく緑化面積に 算入できることが確認できた。面積への算入方法は様々で あり，生垣の長さ×高さ，もしくはみなし緑化面積を乗じ るとしたものが多い。プランター緑化は地表面に直接に緑 化基盤を保持していないため都市の緑被面積に寄与しない ことや, 移動される可能性があるものの, 移動しないこと や植栽基盤の容量を条件に, 12 事例でプランター緑化を緑 化面積に加えることを認めていた。また，9 事例で太陽光 発電装置を何らかの形で緑化面積に算入していることが判 明した。このように，いわゆる緑地とはみなしにくいもの に関しての規定【77補足的緑化誘導規定】も存在していた。

以上の調查により, 全ての事例で緑化率を用いて定量的 な誘導を行おうとしていること、しかしそれを含む全体で 7 つの規定によって緑化に関する具体的な誘導内容が構成 されていることが明らかとなった。それにより, 緑化率の 計算に必要となる緑化面積の算出において, 屋上緑化や壁 面緑化，プランター等を参入するかどうかを規定したり， また緑化の位置により緑化面積の算定方法を変化させたり することで，自治体が望ましいと考える多様な緑化を誘導 できる体系を形成していることが示された。しかし，緑化 面積の算定方法には複数の選択肢が用意され，選択は事業 
者に依存する部分も大きいことも特徵として抽出された。

\section{5。緑化に関する条例等の制定年およひ改正年と名称}

緑化に関する具体的な規定を有する条例等の制定年およ び改正年と名称を調查した。30 事例のうち，昭和期に制定 されたものは 14 事例，平成期に制定されたものは 16 事例 であった。さらに制定期を分類すると，昭和期に制定され た 14 事例のうち都道府県 7 事例の全て, 政令指定都市の 7 事例のうち 6 事例は, 工場立地法や都市緑地保全法(現: 都 市緑地法)が制定された 1972 (昭和 48) 年から 6 年以内に制 定されていた。その後, 10 年程期間が空いて, 1987 (昭和 62) 年 2003 (平成 15) 年に 4 事例が制定され, 残る 11 事例 は2004 (平成 16)～2015(平成 27) 年に制定されている。よ って制定時期を 4 つに分類して整理した。工場立地法や都 市緑地保全法の制定から 6 年以内の 1970 年代を第 I 期, 1980 年代を第II 期, 1990 年代から景観法制定までを第 III 期，景観法制定以降を第 IV 期とすると，第 I 期には 13 事 例が制定されている。第 II 期に制定されたものは 2 事例の みにとどまっている。第 III 期には，4 事例が制定され 5 事例が改正されている。そして第 IV 期には 11 事例が制定 され，9事例が改正されていた。

調査の対象とした条例等(表-2)の名称には，「○○みど
りを守り育てる条例」や「○○緑化指導要綱」といったも の以外に,「○○工場等緑化推進要綱」,「○○景観計画」や 「○○地球温暖化対策条例」といったものがあるため，条 例や要綱といった名詞を除きキーワードとなる名詞を抽出 した。30事例のうち名称に「工場」が入るものは 1 事例 (政 令指定都市), 「景観 が入るものは 3 事例(都道府県 3 事例), 「地球 (温暖化)」が入るものは 4 事例(都道府県 2 事例, 政令指定都市 2 事例), 「建築物」が名称に入るものは 2 事 例(政令指定都市)あった。残りの 20 事例(都道府県 8 事例, 政令指定都市 12 事例)の名称には, 「自然」・環境」・「自然 環境」・緑」・「みどり」・緑化」「樹木」といった，より 広い総括的な言葉が使われていた。

制定時期と条例等の名称キーワードとの関係性を見てみ ると，名称に「工場」が入る事例は第 I 期に制定されてい た。一方で「景観」,「地球(温暖化)」,「建築物」の言葉が 名称に含まれている条例等はすべて第III期と第IV 期に制 定されていた。「景観」が含まれる 3 事例は第 IV 期に制定 されており，鳥取県，奈良県，岩手県であった。「建築物」 が含まれる 2 事例も第 IV 期に制定されており, 大阪市と神 戸市であった。両市ともに大都市であること，高密な大都 市における近年の緑化推進の必要性を意識したものと考え られる。一方で緑や自然環境保全といった一般的な言葉を

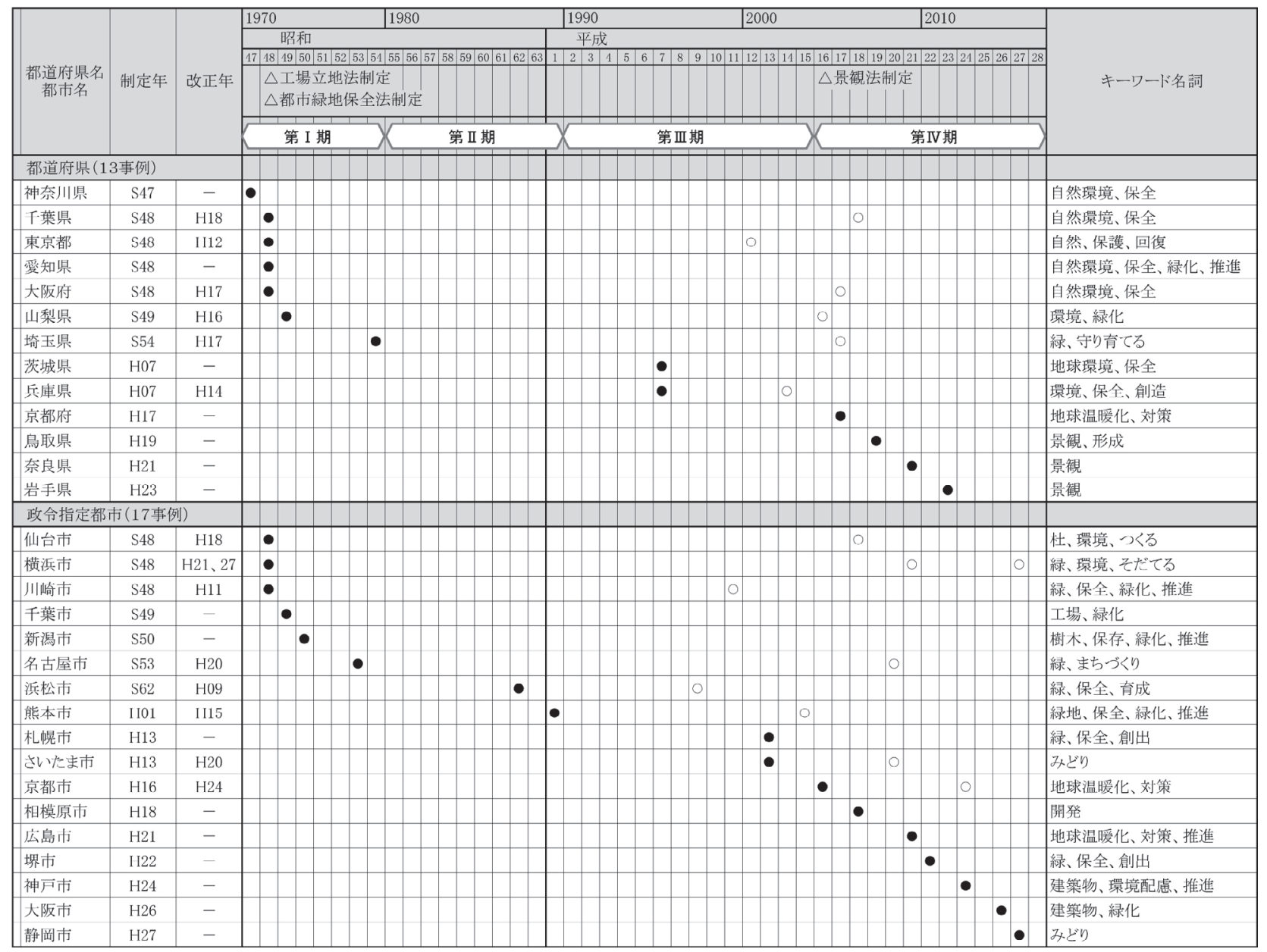

図-2 緑化に関する条例等の制定時期とキーワード は制定年，○は改正年を示す) 
名称の中に持つ条例等は，20 事例中 12 事例が，第 I 期に 制定されているが，それ以外の時期にも分散していた。以 上の内容を整理したものが図-2である。これによって, 制 定時期と名称には関連性があり，名称は緑に対する各時期 の社会意識を反映したものであることが確認できる。第 I
期と第 II 期は公害問題や高度経済成長の弊害に対する自 然環境の保全や都市緑化の重要性が意識されたこと，第 III 期は地球温暖化問題が，そして第 IV 期は景観が社会的 に課題認識されたことを背景に行政施策が取り組んできた 結果とみなすことができる。

表-4＼cjkstart緑化に関する条例等の制定時期と規定構成数の関係

\begin{tabular}{|c|c|c|c|c|c|c|c|c|c|c|}
\hline \multirow{2}{*}{\multicolumn{2}{|c|}{ 緑化に関する条例等 }} & \multicolumn{8}{|c|}{ 定量的緑化誘導規定の構成 } & \multirow{4}{*}{$\begin{array}{l}\text { 規定 } \\
\text { 構成数 }\end{array}$} \\
\hline & & \multirow{3}{*}{$\begin{array}{c}\text { (1) } \\
\text { 緑化誘導刘象 } \\
\text { 規模規定 }\end{array}$} & \multirow{3}{*}{$\begin{array}{c}\text { (2) } \\
\text { 緑化誘導対象 } \\
\text { 分類規定 }\end{array}$} & \multirow{3}{*}{$\begin{array}{c}\text { (3) } \\
\text { 緑化率 } \\
\text { 算出規定 }\end{array}$} & \multirow{3}{*}{$\begin{array}{c}\text { (4) } \\
\text { 緑化量 } \\
\text { 算出規定 }\end{array}$} & \multirow{3}{*}{$\begin{array}{c}\text { (5) } \\
\text { 緑化配置 } \\
\text { 誘導規定 }\end{array}$} & \multirow{2}{*}{\multicolumn{2}{|c|}{$\begin{array}{c}\text { 6) } \\
\text { 建築物上緑化 } \\
\text { 誘導規定 }\end{array}$}} & \multirow{3}{*}{$\begin{array}{c}\text { (7) } \\
\text { 補足的緑化 } \\
\text { 誘導規定 }\end{array}$} & \\
\hline \multirow{2}{*}{ 制定 } & \multirow{2}{*}{$\begin{array}{c}\text { 都道府県名 } \\
\text { 政令指定都市名 }\end{array}$} & & & & & & & & & \\
\hline & & & & & & & $\begin{array}{l}\text { 屋上 } \\
\text { 緑化 } \\
\end{array}$ & 壁面 & & \\
\hline \multirow{13}{*}{ I } & 千葉市 & A & 有 & A & 有 & - & 有 & 有 & プランター & 6 \\
\hline & 埼玉県 & A & 有 & $A \cdot B 1$ & 有 & - & 有 & 有 & 太陽光 & 6 \\
\hline & 千葉県 & B & 有 & A & 有 & - & 有 & 有 & - & 5 \\
\hline & 東京都 & A & 有 & $\mathrm{B} 1 \cdot \mathrm{B} 2$ & 有 & A & 有 & 有 & 生垣 & 7 \\
\hline & 神奈川県 & $\mathrm{C}$ & 有 & A & 有 & - & 有 & 有 & 太陽光/プランター & 6 \\
\hline & |梨県 & A & 有 & A & 有 & - & 有 & 有 & - & 5 \\
\hline & 愛知県 & B & 有 & A & 有 & - & - & - & - & 4 \\
\hline & 大阪府 & A & 有 & $\mathrm{B} 1 \cdot \mathrm{B} 2$ & 有 & - & 有 & 有 & 太陽光/プランター & 6 \\
\hline & 仙台市 & A & 有 & A & 有 & - & 有 & 有 & 生垣/プランター & 6 \\
\hline & 横浜市 & A & 有 & A & 有 & - & 有 & 有 & プランター & 6 \\
\hline & 川崎市 & $A \cdot D$ & 有 & A & 有 & - & 有 & 有 & 生垣 & 6 \\
\hline & 新潟市 & A & 有 & A & - & - & - & - & - & 3 \\
\hline & 名古屋市 & A & 有 & A & 有 & - & 有 & 有 & 生垣/プランター & 6 \\
\hline \multirow{2}{*}{ II } & 浜松市 & A & 有 & A & 有 & - & 有 & 有 & - & 5 \\
\hline & 熊本市 & A & 有 & $\mathrm{A} \cdot \mathrm{B} 1$ & 有 & - & 有 & - & - & 5 \\
\hline \multirow{4}{*}{ III } & 茨城県 & A & 有 & A & - & - & - & - & - & 3 \\
\hline & 兵庫県 & A & 有 & B2 & 有 & - & 有 & 有 & 太陽光 & 6 \\
\hline & 札幌市 & A & 有 & A & 有 & B & 有 & 有 & 生垣/太陽光 & 7 \\
\hline & さいたま市 & A & 有 & A & 有 & - & 有 & 有 & 生垣/プランター & 6 \\
\hline \multirow{11}{*}{ IV } & 岩手県 & $\mathrm{D}$ & 有 & B2 & 有 & - & - & - & 生垣 & 5 \\
\hline & 奈良県 & B & - & A & 有 & - & - & - & - & 3 \\
\hline & 鳥取県 & D & - & A & 有 & - & 有 & 有 & 生垣/プランター & 5 \\
\hline & 京都府 & A & 有 & $\mathrm{B} 1 \cdot \mathrm{B} 2$ & 有 & - & 有 & 有 & 太陽光/プランター & 6 \\
\hline & 京都市 & A & 有 & $\mathrm{B} 1 \cdot \mathrm{B} 2$ & 有 & - & 有 & 有 & 太陽光/プランター & 6 \\
\hline & 広島市 & A & 有 & A & 有 & B & 有 & 有 & 太陽光/プランター & 7 \\
\hline & 大阪市 & $A \cdot D$ & - & A & 有 & B & 有 & 有 & 生垣 & 6 \\
\hline & 神戸市 & A & 有 & B2 & 有 & - & 有 & 有 & 太陽光/プランター & 6 \\
\hline & 相模原市 & $A \cdot C$ & 有 & $\mathrm{A}$ & - & - & - & - & - & 3 \\
\hline & 静岡市 & A & - & A & 有 & - & 有 & 有 & 生垣 & 5 \\
\hline & 堺市 & $C \cdot D$ & 有 & A & - & - & - & - & - & 3 \\
\hline
\end{tabular}

脚注)

制定時期 制定時期に関寸る次の4分類を示寸 $\quad I=1970$ 年代, II =1980年代, III =1990年代から景観法制定, IV=景観法制定以降

(1) それぞれ次の值の大小で誘導対象を規定することを示す。 $\mathrm{A}=$ 敷地面積, $\mathrm{B}=$ 行為面積もしくは行為地面積, $\mathrm{C}=$ 開発区域面積, $\mathrm{D}=$ =建物規模

(2) 緑化の誘導方法を対象によって分類する規定の有無を示す。

(3) 緑化率の分母次の值とを示寸 $\mathrm{A}$ =敷地面積, B 1 =敷地面積一建築面積, B 2 =敷地面積一(敷地面積 $\times$ 建へ流 $\times \alpha$ )

(4) 緑化率の分子となる緑化面積の算出方法の具体的規定の有無考示寸。

(5) 緑化の配置場所に関する規定の有無を示す。有の場合は次の規定によることを示す。 $\mathrm{A}=$ 接道緑化率タイプ， $\mathrm{B}=$ 接道部緑化面積割増タイプ

(6) 建築物上の緑化に関する規定の有無を示す。

（7) いわゆる緑地とは見なしにくいものに関しての規定の有無と、有の場合はその内容を示す。 


\section{6. 考察}

各条例等が 4 章に示寸 7 つの規定(1)〜 (7) をどのように 構成しているかを整理した(表-4)。全 30 事例のうち, す心゙ ての事例で，緑化誘導対象規模規定，緑化率算出規定，緑 化量算出規定，を有していた。7 つの規定をすべて有して いるのは，東京都，札幌市，広島市の 3 事例である。6つ の規定を有しているのは 14 事例であり, 13 事例は緑化配 置誘導規定を有していなかった。5つの規定を有している のは 7 事例であり，そのうち 4 事例は緑化配置誘導規定と 補足的緑化誘導規定を持たない事例, 2 事例は緑化配置誘 導規定と緑化誘導対象分類規定を持たない事例， 1 事例は 緑化配置誘導規定と建築物上緑化誘導規定を持たない事例 であった。有しない規定についてはばらつきが見られた。 名称に「景観」の入る条例等の規定構成は，いずれも緑化 配置誘導規定は有していない。規定数が 5 つから少ないも のは緑化誘導対象規模規定，緑化率算出規定，緑化量算出 規定，の3つのみであった。名称に「地球(温暖化)」の入 る条例等の規定構成は，7 もしくは 6 つであった。名称に 「建築物」が入る 2 つの条例等はいずれも 6 つの規定を有 していたが，有しない規定はそれぞれ，誘導対象分類規定 と緑化配置誘導規定で異なっていた。

さらに，制定時期ごとに規定構成数の平均值を比較した ところ，第 I 期から第 IV 期まで，それぞれ，5.54，5.00， 5. 50，5.00 となり，最も初期に制定された第 I 期が最多で あった。制定時期の新しい第 IV 期ほど規定構成数が多いと いう傾向はなかった。また第 IV 期の内容としても, 緑化配 置誘導規定を有するのは 2 事例/11 事例，建築物上緑化誘 導規定を有するのは 7 事例/ 11 事例, 補足的緑化誘導規定 を有するのは 8 事例/11 事例であった。都市緑化に対する 期待の増加に対応して制定時期を区分したものの，最も時 代の新しい第 IV 期の規定構成数が多いということはなか った。また規定構成の内容にもばらつきがあり何らかの傾 向を見つけることはできなかった。逆に，第 I 期に制定さ れた 13 事例のうち 7 事例で, 補足的緑化誘導規定の太陽光 パネルやプランターといった，近年の議論の中で登場した 事項に関する規定が含まれている。このことから，条例等 が改正される中で新しい状況に対応寸るように規定が補強 されてきているものと解釈することができる。そのため, 制定時に定められた名称には時代背景の影響が見られるも のの，規定の内容については改正を経て概ね似通ってきて いると評価することができる。

事例間で規定の有無に違いが見られたのは，樹木による 緑化以外の要素の扱いであった。補足的緑化誘導規定にお いて，太陽光パネルやプランターを緑化面積にカウントし ている条例等では，屋上緑化や壁面緑化についてもカウン トしており，反対に建築物上緑化誘導規定を有していない もののほとんどは補足的緑化誘導規定を有していなかった。 また，規定内で違いが見られたのは，緑化配置誘導規定と 緑化量算出規定であった。いずれも設定内容によって，自 治体が望ましいと考える細かい、緑化方法への誘導を図るこ
とができるものである。例えば緑化量算出規定のタイプ B -a と B-b は, いずれも樹木 1 本 1 本をカウントする方法で あるが， B-b は植栽時の実際の樹冠面積を計上寸るのでは なく「みなし樹冠面積」として值を設定して計上寸る方法 である。みなし樹冠の設定方法にはいくつかのやり方があ り，樹高別に高木・中木・低木というように分類し，それ ぞれに樹冠面積を割り当てるタイプ(B-b-1 (1), (B-b-2)), 樹高を直接樹冠の直径として割り当てるタイプ（B -b-1(2)）が見られた。樹高別の分類（高中低木）やみなし 樹冠面積の設定等は自治体によって值が異なっており，緑 化方法を詳細に規定することができる。 B-b-1(1) はある程 度以上の高さになると高木を植えても換算面積は同じだが, B-b-1(2) のように計上すると B-b-1 (1) では評価されない ような特に高い樹木を評価することができる。このタイプ を導入しているのは東京都・さいたま市・川崎市の 3 自治 体であるが，いずれも高木植栽を評価するものとみられ， これらの規定がある自治体には高木を植えるインセンティ ブとなっているといえる。しかしこのような詳細な選択肢 を設けることのデメリットもある。多くの自治体ではひと つのタイプではなく，複数のタイプを選択肢として設けて いた。例えば横浜市では 3 種類の計上方法を用意している。 運用方法について横浜市にヒアリングを実施したところ, 市としては基本的には一つの計上方法を推奨しているが, 事業者によって設計の内容に応じた選択と組み合わせをお こなっているとのことであった。このように，算定方法に 関して選択肢を増やすことは，事業者の意向と自治体の要 望が一致している際には適切に機能寸るが，事業者側に計 画の主導権があるため必ずしも自治体が望む緑化が実現す るわけではない。最も望む緑化や計算方法以外にも適用が 可能な選択肢を設けるのは事業の条件が多様かつ複雑であ ることへの対応であるが，選択肢の増加により事業者が最 も数字を確保しや寸い緑化の配置や緑化面積の計算方法を 採用することも多くなる。条例等で緑化を規定している以 上，事業者は必ずいずれかの計算方法で規定をクリアする 必要があるためそうした事態に応じた多様な計算方法を用 意せざるを得ないが，結果的に必ずしも望ましい誘導がで きなくなっているともいえる。

しかし一方で，緑化配置誘導規定において接道部への配 置に対し緑視面積や割増率の導人といったかたちでインセ ンティブを与えて、そうしたデメリットを回避しようとす る取り組みを付加している自治体が数少ないものの確認す ることができた。

\section{7.まとめ}

本研究によって，緑化に関する条例等は，一定の行為に 対して満たすべき緑化率を規定するという単純な枠組みで 議論されているのではなく, (1)緑化誘導対象規模規定, (2) 緑化誘導対象分類規定，(3)緑化率算出規定，(4)緑化量算出 規定，(5)緑化配置誘導規定，(6)建築物上緑化誘導規定，(7) 補足的緑化誘導規定，の 7 つの規定から構成された体系を 
もつことが示された。屋上緑化や壁面緑化はその中の建築 物上緑化誘導規定に含まれていた。

全ての自治体が緑化率算出規定を保持していたが，その 内容を確認した結果，全ての対象事業に適用されるという 条例等の性格上，複数の計算方法が用意され，その選択が 事業者の計画に任される形になっており、そのため緑地面 積が主眼視され，必ずしも効率的に望ましい緑化，効果の 高い緑化を誘導できていない事態が発生してしまうことが 示唆された。

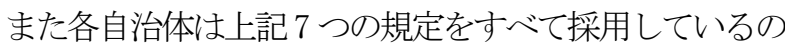
ではなく, 自治体の課題認識に応じて様々に変化している こと，条例等は緑に対する社会的要請を表現していること がそれらの制定年や名称から確認された。現在に至るまで の概ね 4 期に分類できることが示されたが，緑化を規定す る 7 つの規定のうち採用されている規定数が時代と共に増 加しているといった変化は認められず，概衩似通った構成 になっていた。その一方で，緑化配置誘導規定に独自のイ ンセンティブを導入している事例も存在することが明らか になった。

緑化に関する条例等ができておよそ 40 年, 都市緑化に関 する社会的要請は高まり続けているが，これから都市の縮 小時代が到来するに伴い，第 $\mathrm{V}$ 期とも呼ぶべき時代の到来 が想定される。そこでは，新たな制度設計や改正が必要に なるであろう。その際には今回把握した 7 つの規定内容の どの点の精度を高め，適用方法を工夫したらよいか，7つ をどのように組み合わせればよいか, どのような 8 つ, 9 つめの新しい種類の規定の付加を検討すべきかを議論する ことにより，これまで以上に効率的な緑化方法に誘導が可 能になる。そのためには，本研究の成果をもとに，それぞ れの規定の運用，適用の実態と実現された緑化の特徵，そ の効用についての分析など，更なる研究が必要である。

補注

1）世界の都市総合力ランキング 2016 （一般財団法人森 記念財団都市戦略研究所），

http://www. mori-m-foundation. or. jp/ius/gpci/in dex. shtml）によれば, 都市の力を表す分野として経 済，研究・開発，文化・交流，居住，環境，交通・ アクセスの 6 分野を選定し，その中の環境分野の指 標の一つとして「都心部の緑被状況」を選定してい る。

参考・引用文献

1）国土交通省都市・地域整備局公園緑地・景観課 （2016）「新たなステージに向けた緑とオープンスペ 一ス政策の展開について」, http://www. mlit. go. jp/toshi/park/toshi_parkgre en_tk_000064.html，入手日 2017.1.28

2）渡辺達三・恒川篤史・林邦能(1987)「首都圈各市区 における緑化政策の実施状況に関する考察, 造園雑
誌 No.50-5 P293-298

3）御手洗潤・越澤明(2006)「我が国における建築物の 緑化義務を課する法制度に関する比較研究」, 日本都 市計画学会都市計画論文集 №.41-3 p619-624

4）上野由美子・佐土原聡・吉田聡(2005）「東京都にお ける緑化計画書制度の現状と今後の展開に関寸る研 究」, 日本建築学会大会学術講演梗概集 F-1 巻 p1147-1148

5）陳敦琳・小池博・小林正美(2005）「東京都における 私有地緑化政策に関寸る研究, 日本建築学会大会学 術講演梗概集 $F-1$ 巻 $p 441-442$

6）小野寛明(2012）「緑化制度の対象敷地面積要件によ る地価への影響について」, 政策研究大学院大学まち づくりプログラム論文集

7）鈴木弘孝(2013)「公開空地の実態と緑化の特性に関 寸る研究-東京都 23 区を対象として一」，城西国際大 学紀要 第 21 巻 第 8 号 p1-15

8）国土交通省都市局「都市緑化データベース」, http://www. mlit. go. jp/crd/park/joho/database/t oshiryokuchi/index. html 入手日 2017.1.29

9）経済産業省「工場立地法解説」, http://www. meti. go. jp/policy/local_economy/kou jourittihou/hou/houkaisetsu. pdf pp39-41 入手 日 2017.1.29

謝辞

本研究は, 科学研究費補助金(基盤研究(B)（一般)，課題番 号 16H05060)により実施したものである。ここに記して謝 意を表します。 